\title{
Paisaje y diseño en torno a la construcción del templo de San Miguel Arcángel, Santo Domingo de Heredia, Costa Rica, 1879
}

\section{Henry O. Vargas Benavides ${ }^{1}$}

\section{Resumen}

Recepción: 22 de marzo de 2018 / Aceptación: 9 de julio de 2018

Este documento analiza los elementos del paisaje y del diseño alrededor de la construcción del templo patrimonial El Carmen (anterior ermita de San Miguel) durante el siglo XIX en Santo Domingo de Heredia, Costa Rica. Se utilizan las teorías del diseño y la semiótica con el fin de realizar una comparativa visual y textual en conjunto con el documento fundacional del templo de San Miguel, las cartas pastorales de Monseñor Augusto Thiel, entrevistas de campo y las dos representaciones religiosas más importantes del templo, sus santos patronos. Es decir, la simbología del paisaje y elementos de poder en una construcción de adobe de finales del siglo XIX en Costa Rica.

\section{Palabras clave}

Semiótica; iconografía; adobe; siglo XIX; Costa Rica

\section{Abstract}

This document analyzes the landscape and design elements involved in the building of the patrimonial temple El Carmen of Santo Domingo of Heredia (former chapel of San Miguel) during the XIX century in Santo Domingo of Heredia. Theories of design and semiotics are employed with the aim of performing a visual and textual comparison along with the founding text of the temple of Saint Michael, the pastoral letters of Monsignor Augusto Thiel, field interviews, and the two most representative religious images of the temple, its patron saints. The goal will be the symbolic representation of the landscape and of the power elements in an adobe building at the end of the XIX century in Costa Rica.

\section{Keywords}

Semiotics; iconography; adobe; XIX century; Costa Rica

1 Costarricense. Obtuvo su grado en el Doctorado Interdisciplinario en Letras y Artes en América Central, Universidad Nacional de Costa Rica (UNA). Profesor de diseño en la Sede de Occidente e investigador en el Centro de Investigación en Identidad y Cultura Latinoamericanas (CIICLA), ambas de la Universidad de Costa Rica, Costa Rica. Correo electrónico: henry.vargas@ucr.ac.cr 


\section{Resumo}

Este documento analisa os elementos da paisagem e do desenho ao redor da construção do templo patrimonial El Carmen (anterior capela de San Miguel) durante o século XIX em Santo Domingo de Heredia, Costa Rica. Utilizam-se as teorias de desenho e da semiótica com o objetivo de realizar um comparativo visual e textual em conjunto com o documento fundacional do templo de San Miguel, as cartas pastorais do Monsenhor Augusto Thiel, entrevistas de campo e as duas representações religiosas mais importantes do templo, seus santos padroeiros. Ou seja, a simbologia da paisagem e elementos de poder em uma construção de adobe de finais do século XIX na Costa Rica.

\section{Palavras chave}

Semiótica; iconografia; adobe; século XIX; Costa Rica

\section{Introducción}

En este documento se analizan simbólica y visualmente los referentes fundamentales que nos ocupan, el ícono de un templo de adobe en Costa Rica, su patrono San Miguel y su actual patrona la Virgen del Carmen. Para comprender a grandes rasgos la definición de paisaje se acoge el término acuñado por la UNESCO y la Convención del Patrimonio Mundial que designan al paisaje desde una categoría artística y otra territorial. En la primera categoría el paisaje es visto desde la "pintura o dibujo que representa cierta extensión de terreno; porción de terreno considerada en su aspecto artístico" (Rigol, 2004, p. 10). Desde la categoría territorial como un sistema que luego desmenuza en otras categorías menores y lo resume, Rigol lo resumen de esta manera:

tomado por componentes y complejos de diferente rango tomados bajo la influencia de los procesos naturales y de la actividad modificadora de la sociedad humana en permanente interacción y desarrollo ... En general, se define el paisaje como un sistema integrado por componentes y complejos diversos formados bajo los procesos naturales y antropológicos, en permanente interacción y desarrollo (Rigol, 2004, p. 10).

El término paisajismo desde la arquitectura posee un carácter multidisciplinar, ya que integra creatividad y conocimiento, estética e ingeniería y lo convierte en toda "una profesión cuyo objetivo principal es el sinergismo o integración del arte y la ciencia para el manejo, planeamiento y diseño del entorno físico y cultural, incluyendo los eriales silvestres, los territorios urbanizados y el entorno de las edificaciones" (Rigol, 2004, p. 10). Por su lado, el paisaje natural se establece como "un paisaje constituido principalmente por componentes y complejos formados bajo la influencia de procesos naturales" (Rigol, 2004, p. 10). No obstante, el concepto integral de análisis será el de paisaje cultural, desarrollado por Carl O. Sauer (1889-1975) en 1925, el cual "se crea a partir de un paisaje natural por un grupo cultural. 
La cultura es el agente, la naturaleza es el medio, el paisaje cultural es el resultado" (Rigol, 2004, p. 11).

Hacia 1992 la UNESCO y el Comité de Patrimonio Mundial amplían la definición al detallar que

Esta innovadora decisión con respecto a un tipo de patrimonio tan complejo que enfoca la interacción entre la naturaleza y la cultura y que al mismo tiempo está muy estrechamente relacionado con las formas de vida tradicional, fue un testimonio del carácter avanzado y dialéctico de la Convención ... Los paisajes culturales representan la obra combinada de la naturaleza y el hombre definida en el artículo 1 de la Convención. Los mismos ilustran la evolución de la sociedad y los asentamientos humanos en el transcurso del tiempo, bajo la influencia de las restricciones físicas y/o las oportunidades presentadas por su ambiente natural y de las sucesivas fuerzas sociales, económicas y culturales, tanto internas como externas. Los paisajes culturales deberán seleccionarse sobre la base de su valor universal sobresaliente y de su representatividad en términos de una región geocultural claramente definida y, en consecuencia, por su capacidad para ilustrar los elementos culturales esenciales y distintivos de dichas regiones ... El término paisaje cultural abarca una diversidad de manifestaciones de las interacciones entre la humanidad y su ambiente natural (Rigol, 2004, p. 11).

\section{Ubicación y antecedentes del objeto de estudio}

Los autores del libro Al occidente del Abra. Historia monográfica de Santo Domingo de Heredia (1999), Rafael Bolaños (historiador) y Floria Arrea (arqueóloga), indican que la historia precolombina del cantón ${ }^{2}$ se sitúa a unos 3000 años, gracias a la evidencia de artefactos de piedra, hueso, recipientes de barro, vasijas, ollas, cimientos de casas, entre otros. Por lo que existen alrededor de unos 20 sitios arqueológicos que han sido registrados a lo largo de todo el cantón. Los conquistadores Juan Vázquez de Coronado y Juan de Cavallón advirtieron que los grupos indígenas de esta región eran los del pueblo de Toyopán al noreste de Curridabat, posterior al río Virilla, asentamiento del cacique Yurustí o Yoruste que, a la vez, era principal del cacique Garabito o Coyoche. Dicho pueblo también tenía relación con otros del Valle Intermontano Central como Garavito, Botos, Catapas, Tices, las del Abra, Accerri, Guarco, Pacacua, entre otros, y hasta las márgenes del río Barranca en el Pacífico.

En un artículo inédito, el historiador Rafael Bolaños argumenta que el sector de

La Canoa fue el sitio más importante y en donde se centró el gobierno de Yorustí. La población fue expandiéndose hacia Castilla y la establecida en Cuatro Esquinas, se había expandido hacia el suroeste hasta el centro del Barrio El Socorro, y fue conocida como el Jagüey (en prensa).

Al momento de la conquista muchos indígenas fueron sometidos a los españoles o trasladados en conjunto con los poblados de Barva. Luego

2 En Santo Domingo de Heredia, Costa Rica.

Cuadernos Inter.C.a.mbio sobre Centroamérica y el Caribe, Vol. 15, No. 2, octubre 2018-marzo 2019, 64-94 https://revistas.ucr.ac.cr/index.php/intercambio / DOl: https://doi.org/10.15517/c.a..v15i2.34641 
Santo Domingo empezó a ser poblado por colonos y mestizos en el siglo XVI. Del pasado o herencia colonial al día de hoy se encuentran caminos, acequias empedradas, puentes, cimientos de casas, beneficios de café, paredes de adobe derrumbadas, cerámica hecha por indígenas, vajilla española de loza vidriada con esmalte de estaño producida por esclavos, fragmentos de vidrio y de hierro (Bolaños, 1999, pp. 24-28). En el siglo XVII la actividad cacaotera cae en picada, por lo que muchas familias migran del Atlántico; así mulatos, negros y esclavos se establecieron en Santo Domingo. En el siglo XVIII el terrateniente Antonio Aurelio Zamora deja sus propiedades a su hijo Juan José y este a los ancestros de varios de los actuales domingueños (Bolaños, 1999, p. 36).

El historiador presbítero Manuel Benavides Barquero comenta que el 12 de enero de 1789 unas 3432 manzanas de las tierras de San Miguel, denominadas en aquel momento Tibás o Villa Vieja, se subastaron en la Plaza Mayor de León Nicaragua a unos 319 vecinos, entre ellos españoles nobles, nueve mujeres, españoles, mestizos e indígenas pobres, población que da origen al actual poblado del distrito (Benavides, citado en Sojo, 2012). Estas tierras pasaron a convertirse en pastizales de ganado y en chacras con diferentes productos para la subsistencia, por ejemplo, el trapiche y el trigo. Luego se desarrolla la producción tabacalera hacia 1766 de la cual existe amplia evidencia arqueológica en el distrito central, Tures, San Miguel y Santa Rosa. Es hasta inicios del siglo XIX que empieza a citarse el nombre de Santo Domingo, antes conocido como el paraje de Tibás o el Jaboncillo, a razón del crecimiento y congregación de vecinos. Hacia 1829 los vecinos solicitan construir una primera iglesia, pues dependía eclesiásticamente de Heredia. Las gestiones lograron contar con el apoyo de un cura y se logró erigir la parroquia de Santo Domingo en 1854.

Según estos autores (Benavides, citado en Sojo, 2014), ya hacia la primera mitad del siglo XIX se empieza a cultivar el café, luego de ser introducido este grano a finales del siglo XVIII. Para entonces es común contar con cafetales a lo largo del cantón donde también se sembraba caña de azúcar, trigo y maíz. Es el café el que desarrolla parte importante de la producción nacional durante ese periodo y el que enriqueció al cantón gracias a sus exportaciones. San José y Heredia fueron pueblos que se establecieron en su mayoría gracias a la migración de personas provenientes de Cartago. Otro punto determinante es que la vinculación de Heredia con San José fue de gran provecho para desarrollar la economía de Santo Domingo mediante la producción del café, situación que provocó el aumento de la inmigración hacia el pueblo. El más reciente informe producido sobre el sitio arqueológico denominado Anselmo ${ }^{3}$, ubicado en el distrito de San Miguel, arrojó los siguientes hallazgos:

$3 \quad$ Este sitio fue destinado a la construcción del Centro de Control de Energía del Instituto Costarricense de Electricidad (ICE). Dicho centro fue inaugurado en enero de 2018 y se ubica contiguo al cementerio local. 
fragmentos cerámicos donde se pueden inferir la forma de ollas globulares y escudillas trípodes, algunos pastillajes e incisos que se asociaron a los complejos cerámicos Curridabat y Cartago. También se halló algunos restos cerámicos del periodo Colonial. Este material se encontró a nivel superficial, lo cual aumenta la probabilidad de que se reporten rasgos culturales en estratos profundos (Monge, 2009, p. 13).

En total se recuperaron 5230 fragmentos precolombinos y una cuenta de vidrio, losas, ladrillos y metal en la operación 1 y 12177 materiales en la operación 2 en donde abunda el material cerámico precolombino y lítico, además de otros materiales. Entre la presencia cerámica se detectaron "soportes grandes y bases de los jarrones trípodes, figuras zoomorfas decorativas, bordes y cuerpos" de material de las fases Curridabat (400800 d. C.), Pavas (300 a. C.-300 d. C.) y Cartago (800-1500 d. C.) y material histórico de la colonia (1500-1821 d. C.). En cuanto a los motivos decorativos se clasificaron en aplicaciones plásticas, impreso-estampado y pintura. Algunas de las representaciones zoomorfas son del zopilote rey (Cathartidae), pava (Cracidae) y paloma (Columbidae), del lagarto, algunas antropomorfas y pinturas con tonos morado, blanco, negro o policromo, algunas piezas provenientes de la Gran Nicoya, además de la cerámica de uso doméstico y ceremonial, así como una ocarina. Se documenta la presencia de fosas funerarias con sus marcadores y otras piezas de lítica para el procesamiento de plantas y semillas (Monge, 2012).

\section{San Miguel: el espacio que nos ocupa}

Hacia el año 1904 el Diccionario geográfico de Costa Rica de Noriega ubica y contextualiza el distrito de San Miguel en los anteriores distritos de Tures y Pará. El diccionario describe a inicios del siglo XX algunos aspectos sobre la visión del espacio por tratar, elementos que luego se comparan con el texto de la fundación de la ermita de San Miguel o Templo Patrimonial El Carmen. Se menciona la topografía quebrada del lugar y el Raicero, sitio en el Barrio del Socorro, en donde todavía se aprecian los frondosos higuerones y sus prominentes raíces que le caracterizan y dan nombre a ese amplio caserío del hoy distrito migueleño. Sobresale igualmente el río Tibás, afluente del Virilla, que divide los distritos de Tures (Los Ángeles) y San Miguel, el cual conecta con el centro del cantón. En este texto se aprecian otros elementos del paisaje, terrenos fértiles, variedad de productos agrícolas ya mencionados -y que se han cultivado desde la época prehispánica como el cacao y el tabaco- y otros desde la Colonia, como la caña de azúcar y trigo, además del notable lugar que se le otorga al café y la maquinaria alrededor de este en conjunto con la industria de la caña.

San Miguel de Santo Domingo, antes se llamó Raicero, es el segundo distrito del Cantón del mismo nombre de la provincia de Heredia, situado al este de la cabecera y a una distancia de $31 / 2 \mathrm{~km}$, se halla dividido en dos caseríos 
denominados San Miguel Norte y San Miguel Sur o Tures divididos por el río Tibás, afluente del Virilla. Su suelo es muy Quebrado y la topografía muy atrayente. San Miguel Sur se distingue por la fertilidad de sus terrenos y por el levantado espíritu público de sus habitantes, como lo demuestra una magnífica cañería costeada por cinco vecinos con la circunstancia muy honrosa de haber construido ellos mismos el tubo madre todo de hierro y en el mismo distrito. Existe también una Iglesia y casas de enseñanza, un beneficio de café movido por vapor y cinco más de segundo orden y cuatro trapiches. Produce muy buen café, caña, hortalizas, trigo, tabaco y cacao en los bajos; el clima es frío y en parte templado. El distrito está unido a la cabecera del cantón por una magnífica carretera y tiene los siguientes caminos vecinales: uno que partiendo del suroeste conduce a San Vicente de San José como de $2 \mathrm{~km}$, otro al noreste de $21 / 2 \mathrm{~km}$ que va a San José de San Isidro de Heredia y otro al sureste que va a San Jerónimo y por último el que conduce a San Isidro de Heredia. 1223 habitantes (Noriega, 1904, p. 189).

Sobresale en ese paisaje rural su iglesia y algunas escuelas existentes. En 1896 se menciona a San Miguel como distrito escolar, pues anteriormente la escuela funcionaba en casas de habitación. Luego se establece el Centro Educativo Castilla, fundado en 1912, y la desaparecida Escuela Mixta Montero, ubicada en Calle Nueva y construida en 1913 (González, 1991).

El diccionario de Noriega señala el río Tibás que también da nombre al cantón josefino y a la amplia zona del raicero (San Miguel), los cuales conformaron una sola unidad territorial desde la época prehispánica. Este afluente conforma un importante caudal que se une luego al río Virilla, de los ríos principales del Valle Intermontano Central, que luego confluyen en el Grande de Tárcoles.

Tibás: Riachuelo que nace en las faldas del cerro Zurquí dentro del cantón de San Rafael de Heredia; pasa al de Santo Domingo dividiendo a San Miguel Norte de San Miguel Sur o Tures y desemboca en el Virilla (Noriega, 1904, p. 218).

\section{El Templo Patrimonial El Carmen, antigua ermita de San Miguel}

El Templo patrimonial de El Carmen, anteriormente primer templo de San Miguel, del distrito tercero de Santo Domingo de Heredia, se encuentra a unos 1275 metros sobre el nivel del mar. Inició su construcción en 1878 y finalizó en 1879. Es una construcción de adobe, maderas finas, basas de piedra y tejados principalmente. Fue declarado reliquia de interés arquitectónico, histórico y cultural el 22 de abril de 1982, posteriormente patrimonio nacional el 17 de diciembre de 1998, según decreto número 27493-C, Gaceta n. 245, del gobierno de la República de Costa Rica (Centro de Conservación del Patrimonio Cultural).

En el documento sobre la fundación del templo de San Miguel ${ }^{5}$, redactado en 1879 por los vecinos del barrio de San Miguel, también conocido como el

$4 \quad$ Conocido actualmente como San Josecito.

5 Archivo Arquidiocesano (1879). San Miguel de Santo Domingo. N. 22-B (Ver anexo).

Cuadernos Inter.c.a.mbio sobre Centroamérica y el Caribe, Vol. 15, No. 2, octubre 2018-marzo 2019, 64-94 https://revistas.ucr.ac.cr/index.php/intercambio / DOl: https://doi.org/10.15517/c.a..v15i2.34641 
Raicero, y localizado en el Archivo Arquidiocesano de San José, se señalan las siguientes características:
a) Río caudaloso
b) Patrono traído de Guatemala
c) Construcción del templo iniciada en 1878
d) Descripción del sitio de la construcción y características fundamentales
e) Sus habitantes

\section{Río caudaloso}

Lo que impide a los vecinos trasladarse hasta la parroquia de Santo Domingo a escuchar los oficios religiosos es un río caudaloso que en los meses de invierno les imposibilita cruzar. Este río es el Tibás, afluente del Virilla y que en su momento no contaba con puentes para atravesarlo. Aparte de lo quebrado del terreno en sus márgenes, se consideran pendientes profundas que tenían que atravesar. Al igual, cruzar el río Virilla hacia San José mantiene un cañón mayor que el anterior. En el texto se indica que la distancia hasta el centro del cantón es de una y media legua, que en total es de 7,2 kilómetros.

Varias de estas rutas eran indígenas y conectaban por las márgenes del Virilla, hasta llegar al centro del cantón y continuaban a Cubujuquí o Heredia. En el siglo XVII algunos pobladores descendieron de la provincia de Cartago y arribaron al cantón de Heredia por la parte más estrecha del Virilla, en los sectores del Raicero y la Presa, en el distrito de San Miguel, quienes continuaron su trayecto hasta desarrollar la ciudad cabecera de la provincia de Heredia. En la siguiente figura se aprecia el mapa del cantón de Santo Domingo y su actual división distrital. La línea gris oscura señala el recorrido del Río Tibás desde su paso en el sector noreste, entre los distritos de Tures y Pará, hasta continuar su descenso entre los distritos de Tures y San Miguel y, este último, con Santo Tomás. La flecha señala dos de las rutas desde el Templo Patrimonial de El Carmen (Ermita o antiguo Templo de San Miguel), para cruzar el distrito de San Miguel, hacia el distrito central de Santo Domingo, una con dirección a Tures y la otra al distrito de Santo Tomás, para luego llegar al cantón central.

Rafael Bolaños (2018) detalla que para los puentes de arco del cantón se contrató al ingeniero José Riggioni a mediados del siglo XIX, esto gracias al auge cafetalero que experimentaba la localidad y el país, aparte de la cantidad de granos y hortalizas que se producían en los distritos del este del cantón (actuales San Miguel, Tures, Pará y Paracito) y que comerciaban en la capital y en el puerto. Solo los puentes construidos en el distrito de San Miguel se iniciaron hasta finales del siglo XIX para unir a "el río Tibás en San Miguel Sur y otro en San Miguel norte, hoy distrito de Tures y que costó cada uno menos de dos mil pesos oro", de allí lo complejo que impedía cruzar a la población por los altos caudales de invierno en los ríos Tibás, Tures, Pará y Virilla. 
Figura 1. Mapa del cantón y recorrido desde la antigua Ermita al distrito central.

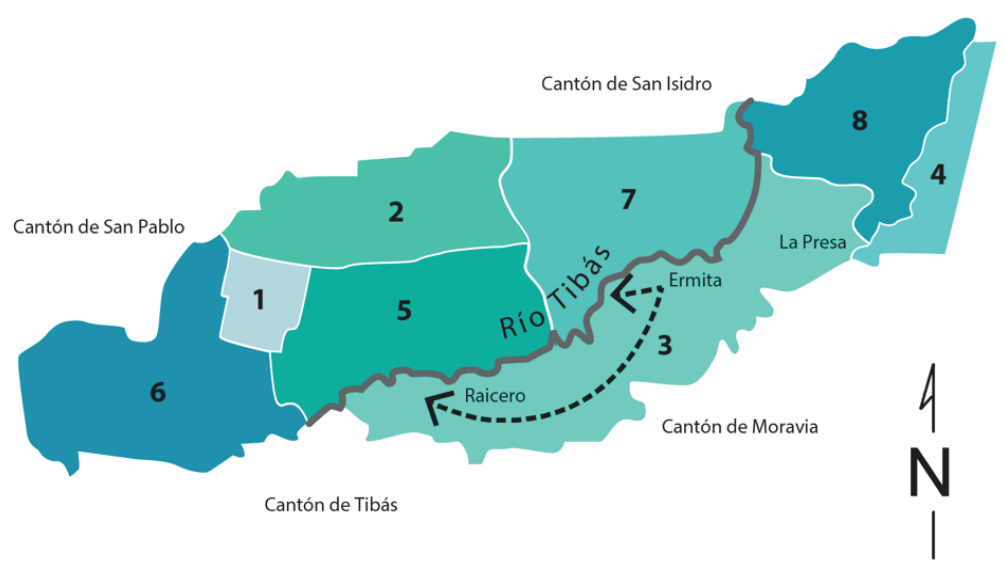

Distritos de Santo Domingo

1. Santo Domingo (Central)

2. San Vicente

3. San Miguel (San Miguel Sur)

4. Paracito
5. Santo Tomás

6. Santa Rosa

7. Tures (Ángeles)

8. Pará (San Luis)
Simbología

Río Tibás

Fuente: Vargas, 2017.

\section{Patrono traído de Guatemala}

El comercio de Santo Domingo durante el siglo XIX y hasta inicios del siglo XX casi mantuvo la misma ruta colonial desde Cartago hacia el Pacífico, la cual pasaba por San José, Heredia, Alajuela, y continuaba luego a La Garita por el Río Grande a los Montes del Aguacate, Esparza y hasta Puntarenas. Este trayecto principal en Costa Rica fue conocido como el Paso Real. En los siglos XVI al XVIII el Virilla tuvo un pasaje importante que conectaba con el valle de Barba, cercano al distrito de Santa Rosa de Santo Domingo conocido como Paso del Montano. Muchas de las carretas del cantón transitaron por este camino entre 1845 a 1882 para llevar el café costarricense y exportarlo por el Pacífico hacia Londres, Hamburgo, San Francisco y Nueva York, como sus principales mercados. Además, por el puerto de Puntarenas ingresaban muchos productos importados; con la construcción del ferrocarril al Atlántico en 1870 se abrió una nueva vía comercial que conectaba con Puerto Limón en el Caribe (Rodríguez y Sáenz, 2016).

En el texto de la fundación aparece la ubicación del templo construido en un solar que fue donado por dos vecinos. En el primer párrafo detallan lo siguiente: "propusimos hacer venir de Guatemala, una imagen de nuestro Patrono San Miguel". De acuerdo con la entrevista realizada a Emilce Salas (2017), vecina de la localidad y nacida en 1935, su padre Bolívar Salas Sánchez (1907-2000) le decía 
que su bisabuelo Francisco Sánchez (1831-1900) (Figura 3), originario de México y radicado en este territorio, junto con su amigo Santos Chacón Sancho (18231895) (Figura 2), fueron no solo los donantes del terreno en donde se construyó el inmueble, sino también los que trajeron de Guatemala la imagen de San Miguel Arcángel y los que financiaron gran parte de la construcción del templo. Los caminos de carretas mencionados anteriormente cumplieron a cabalidad con el progreso que empezaban a experimentar nuestros pueblos, pues gracias al denominado grano de oro ${ }^{6}$, se pudieron adquirir piezas artísticas de alto nivel. Para el templo se obtuvieron lámparas de cristal cortado y otras piezas artísticas, así como obras de imaginería para fines sacro o de uso público y privado.

Figura 2. Fotografía de Santos Chacón Sancho (1823-1895), dibujo a lápiz, finales del siglo XIX.

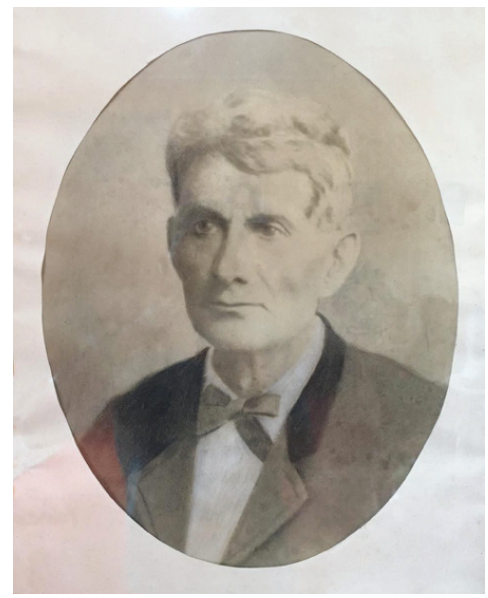

Figuras 3. Fotografía de Francisco Sánchez (1831-1900), dibujo a lápiz, finales del siglo XIX.

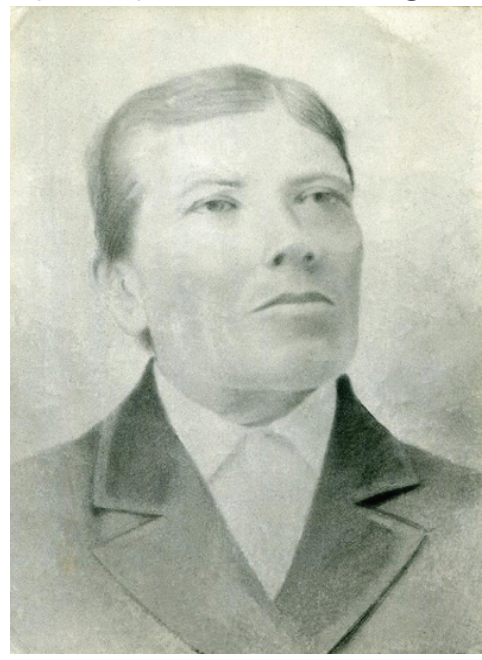

Fuente: Vargas, 2017.

$6 \quad$ Así se denominaba al grano de café costarricense durante esa época.

Cuadernos Inter.c.a.mbio sobre Centroamérica y el Caribe, Vol. 15, No. 2, octubre 2018-marzo 2019, 64-94 https://revistas.ucr.ac.cr/index.php/intercambio / DOI: https://doi.org/10.15517/c.a..v15i2.34641 
Varias de las viviendas contaban con oratorios en donde los familiares, la mayoría fervientes de la doctrina católica, tenían un espacio reservado para la oración y veneración de la imaginería religiosa nacional o extranjera. En la misma entrevista Emilce Salas aclara sobre el oratorio en la casa de Eudocia Chacón, nacida en 1868, hija de Santos Chacón Sancho y María Josefa Barquero. En algunas casas de Santo Domingo se conservan espacios como esos antiguos oratorios; tal ejemplo se registró durante el 2016 en la visita y entrevista a María Aurelia (Lela) Azofeifa Barquero (1918-), en Santo Tomás, hija de Fulgencia Barquero Zamora, conocida como Lencha. El oratorio es un aposento en el ala derecha de la casa donde existen diferentes tipos de imaginería religiosa, camarines y mobiliario para albergarlos.

Figura 4. Fotografía de la imagen de oratorio de la casa de María Aurelia (Lela) Azofeifa Barquero en Santo Tomás de Santo Domingo.

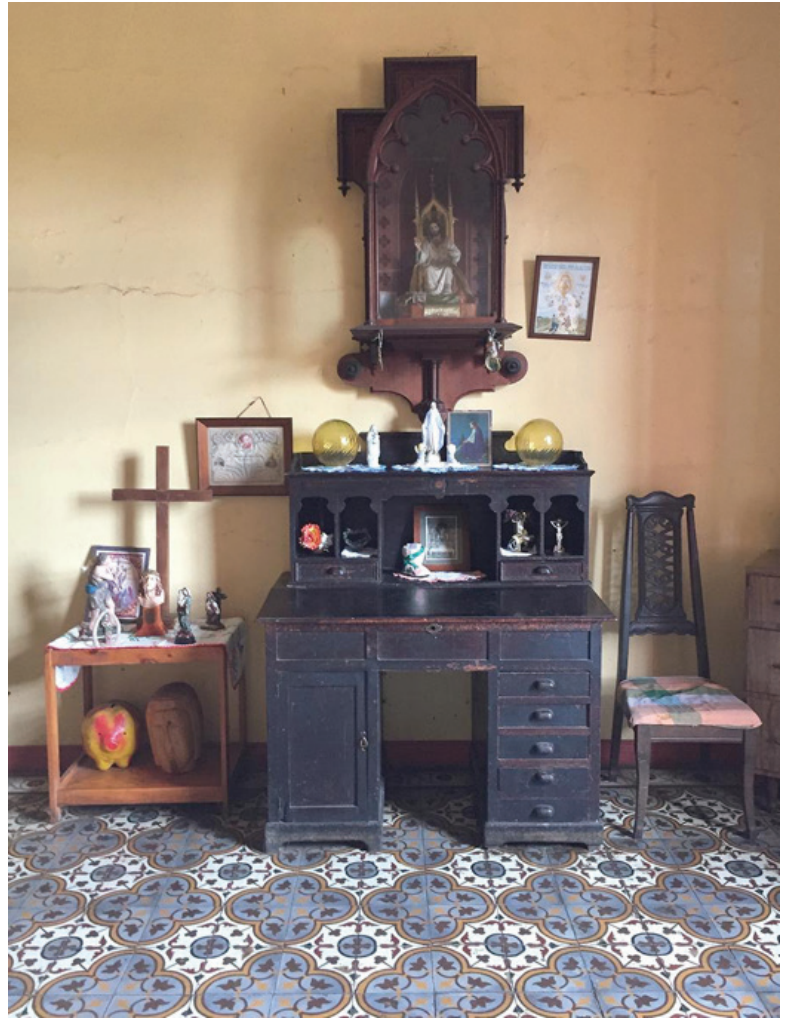

Fuente: Vargas, 2016.

En el documento presentado por Óscar E. Solórzano Alfaro sobre la Restauración Iglesia del Carmen Sn. Miguel, Sto. Domingo Heredia (1980), se detalla que en varias entrevistas realizadas a vecinos del lugar, se precisan datos aportados por Emilce Salas y varias intervenciones que ha tenido este templo de adobes. Asimismo, se confirma la donación del terreno por 
parte de estos dos personajes; entre los entrevistados están Leonor Solano Villalobos y Jovita Chacón, descendientes de Santos Chacón Sancho y Leonidas González, hijo de Tranquilino González Ruiz (1864-1900) (quien también ayudó a la construcción del templo) y Manuela Sánchez Salas (18941990), descendiente de Francisco Sánchez?.

El San Miguel de Guatemala es de vara y media de altura (1,25 metros). La imagen fue traída el año anterior a la construcción de la iglesia, en abril de 1877. Es una talla en madera ${ }^{8}$, de bulto completo y con esgrafiado ${ }^{9}$. Haroldo Rodas (1992) comenta que desde la Colonia, en el Reino de Guatemala, muchos indígenas se especializaron en la talla de imaginería religiosa y en la pintura, en donde se mezcla la sabiduría ancestral prehispánica con la enseñanza de los frailes y luego la venida de maestros españoles, para desarrollar un arte sincrético a partir del siglo XVII y de amplio reconocimiento dentro y fuera de Guatemala. En muchos de los templos u oratorios centroamericanos dominan las representaciones de la iconografía guatemalteca, además de la española, de América del Sur o de México. Sin embargo, de las obras artísticoreligiosas del Reino de Guatemala, el analista José Mobil, citando a Juarros, comenta lo siguiente: "Las obras de los escultores de guatemaltecos eran muy solicitadas, no solo en el Reino de Guatemala, sino aún en el mexicano y algunas que se han llevado a Europa fueron muy celebradas y aplaudidas" (1995, p. 220).

La imagen de San Miguel Arcángel traída desde Guatemala por Santos Chacón y Francisco Sánchez se convirtió en el ícono de este pueblo herediano que por sus características ${ }^{10}$ destaca el movimiento curvo de su cuerpo, piernas y brazos. Es de notar el realismo en la mirada producto de sus ojos vidriados, alas atornilladas, al igual que el ramaje de su corona, espada de madera y balanza de plata. Destaca el laminado en oro, con su claroscuro que le brinda mayor profundidad al movimiento de su traje, el tono plata de su armadura, los rosas, celestes, verdes escarlatas; asimismo sobresale una pierna desnuda, lo que brinda un movimiento dinámico de ágil elegancia entre esta y la espada que cierra con la mirada hacia lo alto,

$7 \quad$ Ambos aparecen con sus firmas en el texto de la fundación (Ver anexo).

8 Principalmente eran talladas en cedro por la suavidad de la madera (Rodas, 1992).

9 El esgrafiado "o rayado que se efectuó sobre la capa de oro, previo a la aplicación de una capa de pigmento elaborado al temple, quedando al fondo la capa de oro" (Rodas, 1992).

10 Sobre el barroco y el barroco latinoamericano confróntese el estudio de María Salvadora Ortiz (1988) en donde sintetiza los aportes de Severo Sarduy y Alejo Carpentier al barroco latinoamericano. Incluso como Carpentier contrapone la posición de Eugenio D'Ors y define una categoría latinoamericana bajo la dominancia de un arte alrededor de la exuberancia, la naturaleza, la vegetación, la cosmogonía y el mestizaje. Por tanto, no es prolongación del periodo barroco europeo de los siglos XVI al XVIII, sino la transculturación latinoamericana entre el arte europeo, el de América indígena y las conjunciones con los esclavos africanos y los migrantes asiáticos en el continente. Lo que conforma estilos nuevos como el estípite o grandes escuelas en México, Guatemala, Ecuador Perú o Brasil. Es el sincretismo americano en la arquitectura, el arte y literatura al desarrollar obras bajo el conocimiento del europeo, la conjunción con el mundo precolombino en los periodos colonial y poscolonial. 
hacia la izquierda ${ }^{11}$. Cabe señalar que aunque se trata de una escultura de mediados del siglo XIX, su apariencia luce actual debido a la restauración que se le hizo en 1996.

Figura 5. Fotografía de imagen de San Miguel Arcángel. Talla en madera policromada. Segunda mitad del siglo XIX, antes de renovarse.

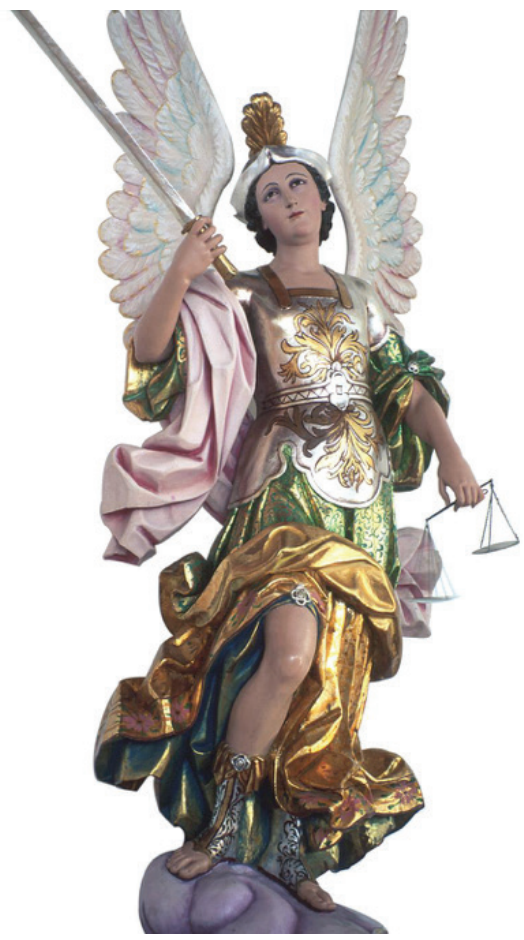

Fuente: Vargas, 1996.

\section{Construcción del templo en 1878}

La construcción de este tipo de viviendas en espacios montañosos y de mayor concentración de humedad en esa época, se hacía en el verano; esto lo pormenoriza el texto fundacional. Dicho factor es clave para entender que los autodidactas ingenieros del templo implementaron técnicas para el procesamiento de adobes de 60 por 30 centímetros y así aprovechar el secado durante la época, incluso mediante la organización de los turnos de verano que muchos de los entrevistados comentan como actividad generadora de fondos. De igual manera, se contó con el refuerzo de animales, en su mayoría bueyes con sus carretas o caballos, que eran aprovechados para batir el barro y otros agentes.

11 Hacia 1996 la imagen se intervino de manera inadecuada, pues se le dio un acabado de color sobre la pintura existente, sepultado los colores originales, por lo que se recomienda hacerle un estudio para verificar si se puede devolverle los colores originales y el laminado de oro que contenía. 


\section{Descripción del sitio de la construcción y características fundamentales}

Más adelante, se describen las características constructivas del templo: 24 varas de largo (20,06 metros), por 11 varas de ancho (9,195 metros), cuenta con tres naves y está construido con adobe, madera labrada y piedra.

El segundo Obispo de Costa Rica, el alemán Bernardo Augusto Thiel, realizó dentro de sus visitas pastorales por Costa Rica, cuatro a la parroquia de Santo Domingo, del 23 al 24 de febrero de 1882, del 13 al 14 de julio de 1888, del 31 de julio al 3 de agosto de 1894 y del 28 de diciembre al 30 de diciembre de 1898. En las cuatro ocasiones siempre visitó la comunidad de San Miguel a caballo y acompañado de su comitiva. En su tercera visita, 1894, cuando el templo migueleño contaba con 15 años de haberse fundado, el Obispo pidió su ampliación a unas 5 varas (4,18 metros) del terreno de la ermita y que todo se titulara debidamente (Herrera, 2009, p. 414).

Durante la restauración en el año 2012, desarrollada por el del Patrimonio Nacional y el proyecto presentado por la comunidad de San Miguel ante Centro de Conservación el Ministerio de Cultura y Juventud, las obras develaron dos etapas constructivas en el templo. En ellas se visualizaron dos tipos de adobes: el más antiguo es liso y, el más reciente, cuenta con dos estrías, el cual se ubica hacia la parte posterior del altar. De la misma manera, se halló una antigua puerta sellada y los adobes similares a los de la casa contigua de Santos Chacón y Regina Vargas. Las medidas coinciden con la ampliación solicitada por Thiel (Benavides, citado en Sojo, 2014).

\section{Sus habitantes}

Más de cuatrocientos habitantes residían hacia el año de 1789, según lo indica el mismo texto fundacional, más otros que por temporadas o estaciones venían a sus fincas desde el centro del cantón. En total unas 100 familias. De acuerdo con los archivos arquidiocesanos sus mismos habitantes se encargaron de darle el debido cuidado y mantenimiento al templo. Hacia 1884 se creó una Junta Directiva inscrita en la Municipalidad y enviada a su cura párroco Benito Sáenz y Reyes que estuvo conformada por los vecinos Florentino Valenciano, Tranquilino González ${ }^{12}$, Joaquín Salas y firmada por el P. Bonilla13.

En el año de 1893 se autorizó al cura Benito Sáenz para bendecir las campanas de San Miguel. Según las entrevistas citadas, el señor Florentino Valenciano donó una de las campanas. Luego las lámparas de cristal cortado se trajeron de Europa en el vapor Limbert, vía Puerto Limón. Luego hacia el año 1900 se instaló el Vía Crucis en la Iglesia del Rosario y en la ermita de San Miguel, donde el cura Benito Sáenz encargó al padre fray Miguel Pages de su colocación.

12 Se respeta la escritura del apellido de época.

13 Caja 321, tomo 1, folio 358, libro 245, fecha 18/9/1884.

Cuadernos Inter.c.a.mbio sobre Centroamérica y el Caribe, Vol. 15, No. 2, octubre 2018-marzo 2019, 64-94 https://revistas.ucr.ac.cr/index.php/intercambio / DOl: https://doi.org/10.15517/c.a..v15i2.34641 
Según los resultados del trabajo de campo se construyó un mapa donde se enumera un sector de San Miguel en el que concentra la ermita o actual Templo de El Carmen y el de la Iglesia Nueva o templo de San Miguel. El mapa de la Figura 6 reúne unas 39 casas, conforme dos informantes (personas adultas mayores), en su mayoría casas antiguas de adobe y bahareque, siglas de lugares como instituciones públicas (escuelas), instituciones privadas (recibidores de café), comercios, medio de comunicación y las casas como tal.

Figura 6. Análisis de casas de adobe y bahareque y otras construcciones a

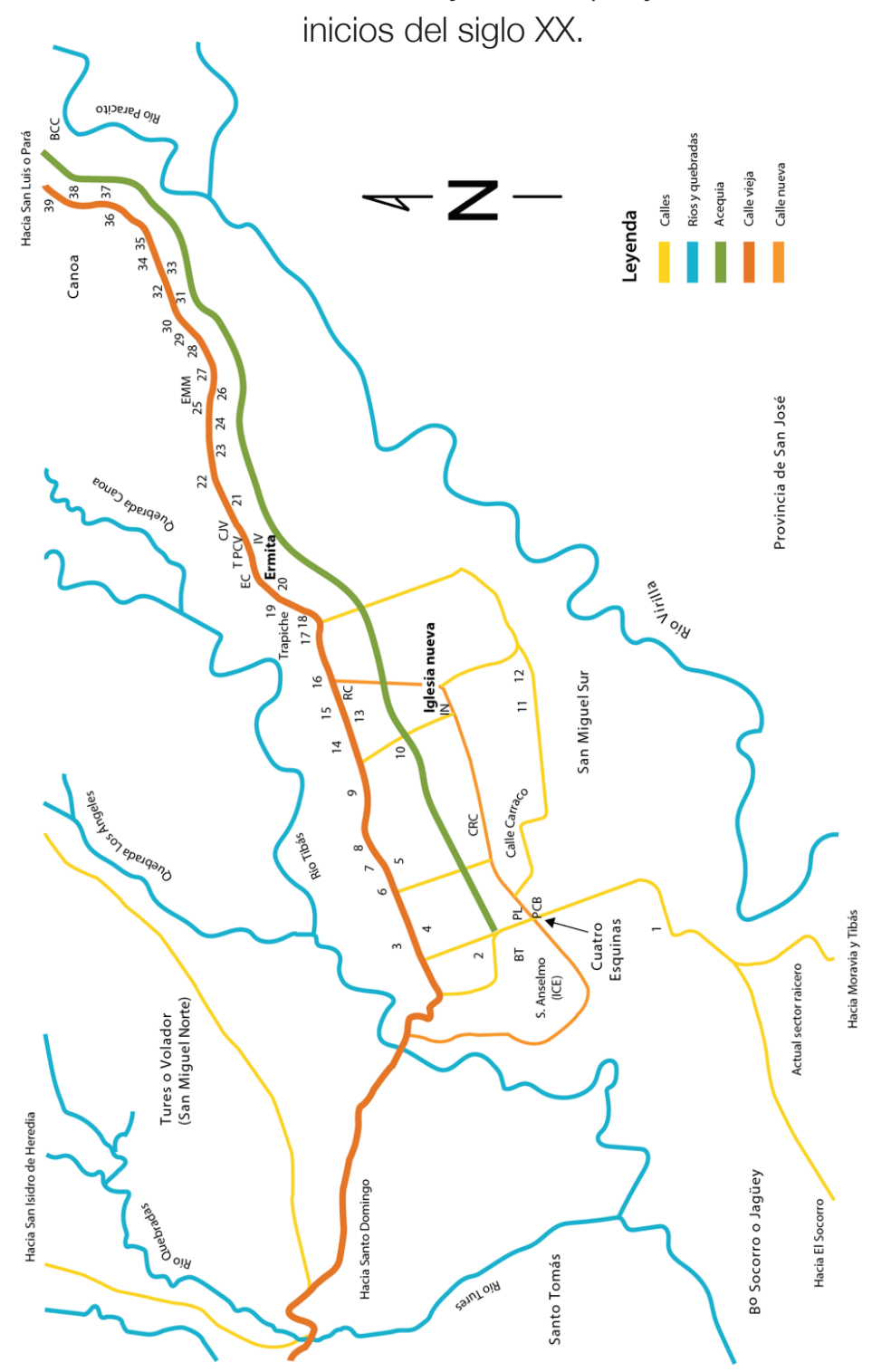

Fuente: Vargas, 2018. 
Cuadro 1. Siglas del mapa

Instituciones públicas
EMM - Escuela Mixta Montero
EC - Escuela Castilla
Instituciones privadas
RC - Recibidor de Café
BT - Beneficio Tournon
Comercio
PCG - Pulpería Carlos García
PL - Pulpería de Lelo
CJV - Carnicería de Juvenal Vargas
PCV - Pulpería Carlos Villalobos
Medios de comunicación
T - Telégrafo

\section{Instituciones públicas}

EMM - Escuela Mixta Montero

EC - Escuela Castilla

Instituciones privadas

$\mathrm{RC}$ - Recibidor de Café

\section{Comercio}

PCG - Pulpería Carlos García

Fuente: Vargas, 2018

Se aclara que antes de $1971^{14}$ San Miguel se componía de San Miguel Norte (actual Tures) y San Miguel Sur, la zona del Raicero, Barrio del Socorro o Jagüey y Pará. La reconstrucción del mapa detalla el nombre de calles, ríos y la acequia expuesta para anegar los cultivos, así como el sitio arqueológico San Anselmo, donde se construyó recientemente el proyecto del Nuevo Centro de Control de Energía del ICE.

Cuadro 2. Casas de adobe y bahareque en San Miguel Sur ${ }^{15}$

\begin{tabular}{|l|l|}
\hline 1- Justo Saborío & 2- Criselda Villalobos \\
\hline $\begin{array}{l}\text { 3- Adrianito Chacón que se encuentra } \\
\text { debajo de la de Paulino Vargas }\end{array}$ & 4- Pilar Chávez (antes vendían pólvora) \\
\hline $\begin{array}{l}\text { 5- Adán Soto, donde vivió Paulino } \\
\text { Vargas }\end{array}$ & 6- Alcimiro \\
\hline 7- Gabriel Soto & 8- Juvenal Villalobos \\
\hline 9- Anita Vargas & 10- Abel Chacón \\
\hline 11- Tobías Córdoba & 12- Luis Araya \\
\hline 13- La de los Jiménez & $\begin{array}{l}\text { 14- Aristides Sánchez, en frente de la } \\
\text { de Remigia, donde vive Rosa Bustos }\end{array}$ \\
\hline $\begin{array}{l}\text { 15- Jobiano Vargas ubicada al lado } \\
\text { arriba de la casa de Rosa Bustos }\end{array}$ & $\begin{array}{l}\text { 16- Nelo Sánchez que estaba un poco } \\
\text { más arriba de la de Rosa Bustos, se } \\
\text { encuentra rodeada por una cerca }\end{array}$ \\
\hline
\end{tabular}

14 Lagartillal ayer, Pará hoy, mi San Luis de siempre. Heredia: manuscrito inédito González, (2016).

15 Informantes: Mario Vargas Valenciano (1927-) y Amparo de la Trinidad Villalobos Chavarría (1929-). 


\begin{tabular}{|c|c|}
\hline $\begin{array}{l}\text { 17- Jaime Salas que vivía un poco más } \\
\text { abajo de la pulpería de Tillo, por donde } \\
\text { antes había un trapiche al lado, por } \\
\text { la entrada de la propiedad de Miguel } \\
\text { Córdoba }\end{array}$ & $\begin{array}{l}\text { 18- Arturo Villalobos que se encuentra } \\
\text { cerca de la pulpería de Tillo }\end{array}$ \\
\hline $\begin{array}{l}\text { 19- Florinda Villalobos, donde antes se } \\
\text { encontraba la pulpería de Tillo }\end{array}$ & $\begin{array}{l}\text { 20- Miguel Villalobos (cerca de la } \\
\text { plazoleta) }\end{array}$ \\
\hline $\begin{array}{l}21 \text { - La de Aurelia, cerca de donde } \\
\text { viven los Calvo, por donde había una } \\
\text { casa muy grande }\end{array}$ & $\begin{array}{l}\text { 22- La pulpería de don Carlos Villalo- } \\
\text { bos }\end{array}$ \\
\hline 23- Teodorico Villalobos & 24- La casa donde vivía el padre Walter \\
\hline 25- Carlos Villalobos & 26- Arcadia Chacón \\
\hline 27- Julio Vargas & 28- Ramón Zamora \\
\hline 29- Jobita Chacón & 30- Casimiro Chacón \\
\hline $\begin{array}{l}\text { 31- Arcelia, donde viven los Nayo, era } \\
\text { una casa grande (Victoria) }\end{array}$ & 32- Heriberto Valenciano \\
\hline 33- José Vargas Cuella & $\begin{array}{l}\text { 34- Florinda González, ubicada debajo } \\
\text { de la de Nane }\end{array}$ \\
\hline 35- León González & 36- Sebastián Barquero \\
\hline 37- Antonio Sánchez & 38- Mardoqueo Sánchez \\
\hline 39- Doña Golla & \\
\hline
\end{tabular}

Fuente: Yunior Marín Solano, 2017.

De este mapa anterior se extrae un nuevo cuadro en donde se presenta nombres de origen prehispánico, nombres castellanos, con posible origen indígena o de uso indígena. Por línea puede observarse el nombre indígena de Jagüey (actual sector del Socorro en San Miguel), su nombre castellano y actual y otro posible origen indígena pero con su traducción al castellano, el Raicero, por las enormes raíces de los árboles hacia el Virilla. Pará, hoy conocido como San Luis o Lagartillal y Paracito, distrito anexo y cercano a este; similar sucede con Tures y los Ángeles, Yurustí o Yuruste y Santo Domingo, calla del carraco (pato cabeciverde o Anas platyrhynchos, Anatidade), Tibás, luego una lista de nombres castellanos y por último nombres de posible uso u origen indígena, como el Volador (por un juego con troncos giratorio en horizontal de origen prehispánico, la acequia para la conducción del agua y de uso en el cultivo desde una posible época prehispánica), canoa o canal para conducir el agua y virilla que presenta dos versiones, una precolombina, derivado de vi o bi, diablo y ri o río (Solórzano, 2014) mientras que la colonial a una dama llamada Elvirilla (de Elvira) (Bolaños, 1999). 
Cuadro 3. Nombres del mapa y separación por origen espacio temporal

\begin{tabular}{|c|c|c|}
\hline $\begin{array}{c}\text { Nombres } \\
\text { prehispánicos }\end{array}$ & Nombres castellanos & $\begin{array}{c}\text { De posible origen o de } \\
\text { uso indígena }\end{array}$ \\
\hline Jagüey & San Miguel & Raicero \\
\hline Pará & San Luis & Paracito \\
\hline Tures & Ángeles & \\
\hline Yurustí o Yoruste & Santo Domingo & \\
\hline Carraco & & \\
\hline Tibás & & \\
\hline Zurquí & & Virilla \\
& Santo Tomás & Canoa \\
& Socorro \\
& Moravia & Volador \\
& San José & \\
& San Isidro & \\
& Heredia & \\
& &
\end{tabular}

Fuente: Vargas, $2018^{16}$.

\section{Elementos de diseño y de la semiótica en sus representaciones simbólicas}

El templo es la figuración divina del cosmos reflejada en su estructura. Como lo señala Jean Chevalier (1986, p. 984) "es la habitación de Dios sobre la tierra, el lugar de la presencia real”. Los templos católicos siguieron el modelo egipcio, hebreo y el románico. Se parte también de la figura de Cristo en la cruz y la posición sagrada del eje del universo manifiesto en sus cuatro puntos cósmicos: este (cabeza), oeste (pies), norte y sur, brazos o manos, respectivamente. Muchos de los principales templos cristianos contemplan la estructura de la cruz o de tres naves, último caso el del Templo de San Miguel. Asimismo la presencia divina se refleja en el altar, donde nace el sol en el este, en el pan eucarístico, símbolo vivo donde yace la divinidad en la tierra; además, es allí donde se coloca al patrono, el arcángel Miguel, capaz de desechar los ángeles rebeldes hacia la profundidad de los abismos, o al mundo indígena de los muertos al entrar por donde se oculta el sol. Chevalier agrega lo siguiente:

Son como réplicas terrenales de los arquetipos celestiales, al mismo tiempo que imágenes cósmicas. Cosmología y teología son así solidarias en la mente de los

16 Sobre el significado de palabras:

Canoa: palabra arauca de las Lucayas. Canal para conducir agua en Costa Rica y Chile (Molinier, 1970). 
hombres, como en sus obras dedicadas a los dioses. El propio universo está concebido como un templo y los místicos convierten el alma humana en el templo del Espíritu Santo (Chevalier, 1986, p. 985).

Otro elemento simbólico característico del templo en estudio es su construcción con bloques de barro (Figura 7), el cual además abarca las construcciones que caracterizaron la mayoría del paisaje domingueño de los siglos XVIII y XIX, es decir, sus casas de adobe y bahareque. Del barro fue formado el primer hombre en el acontecimiento bíblico en el libro del Génesis, es la materia primordial que mezcla la tierra con el agua. Chevalier continúa indicando que la:

mezcla de tierra y agua, une el principio receptivo y matricial (la tierra) al principio dinamizante del cambio y las transformaciones (el agua). Si se toma sin embargo la tierra como punto de partida, el barro simbolizará el nacimiento de una evolución, la tierra que se mueve, que fermenta, que se vuelve plástica ... Si se considera, al contrario, el agua como punto de partida con su pureza original, el barro aparece como un proceso de involución, un comienzo de degradación ... Entre la tierra vivificada por el agua y el agua polucionada por la tierra se escalonan todos los niveles del simbolismo cósmico y moral (Chevalier, 1986, p. 179).

Figura 7. Fotografía del templo patrimonial del Carmen con adobes expuestos durante la restauración del año 2012.

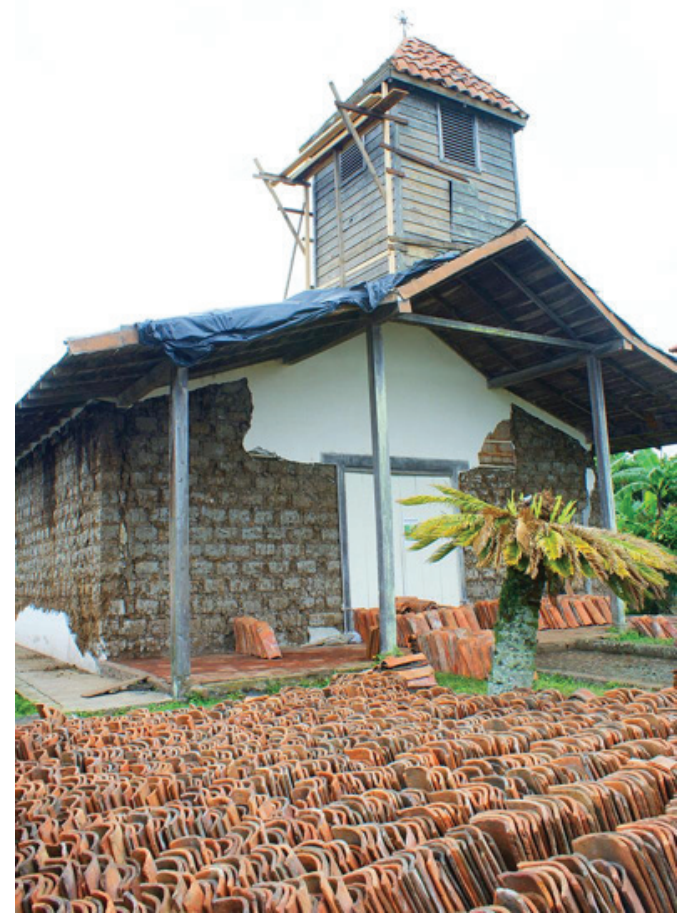

Fuente: Vargas, 2012. 
A diferencia de la creación bíblica en el Popol Vuh", el hombre concebido de barro y luego de madera no funcionó hasta su tercera creación de la masa del maíz. Importante indicar que en la zona de San Miguel se ha continuado cosechando este grano, además de la elaboración de tamales, atoles, mazamorra, chorreadas, cosposas, panes, bizcocho, tamal asado cocido a las brasas y demás platillos. El maíz es ingrediente esencial que ha complementado la dieta domingueña y que se ve reflejada en la cantidad de hornos de barro, cocinas de leña, de las cuales todavía algunas familias utilizan diariamente, así como los antiguos metates para moler o la versión moderna de máquinas metálicas que poseen los dueños de las casas más antiguas de barro o madera, o bien en las familias herederas de la zona. Muchos de estos platillos siguen acompañando los festejos patronales y turnos de verano en varios de los sectores. La celebración de turnos de verano contribuyó con la construcción del templo de San Miguel, y con su restauración entre 1938 y 1954, hasta que se inauguró. Esa hibridez también se refleja en la presencia agrícola combinando la tradición indígena, española y la negra, como se observó atrás.

En los pueblos indígenas de la zona maya, el dios maya del maíz, Jún Ixiim (Iturriga, 2015), se representaba en su traje con muchos brotes, incluso granos o flores, como otras deidades y símbolos de la fertilidad. Se le conoce también como el dios joven del maíz, pues representa el brote, lo nuevo, lo tierno. Esto se emparenta con la semilla como símbolo de resurrección para muchos pueblos indígenas, así como de la victoria sobre la muerte para los cristianos. Algunas de estas formas continuaron decorando las fachadas de templos, pinturas y tallas escultóricas, combinadas con las traídas de fuera del continente. En la talla de San Miguel, además del rostro joven del patrono, abundan en su traje las representaciones de largas hojas, de brotes, así como de flores. El dios del maíz es símbolo de la vida y la muerte, de la resurrección en el mundo indígena, al igual que en la profesión cristiana el arcángel Miguel es el guerrero que lucha contra el enemigo, el que trae la muerte y lo indisoluble, el pecado. Varias de las posiciones del dios del maíz en mesoamérica es de danzantes, similar al delicado movimiento presentado en las figuras de estos arcángeles barrocos latinoamericanos. Ambos también con su corona de plumas o follaje; de hecho, en el dios joven del maíz en Copán se observa esta característica (Grube, 2000, p. 264). Otro rasgo particular es que la festividad de San Miguel se celebra el 29 de septiembre, cuando se cosecha el maíz tierno y se hacen chorreadas, bizcochos y panes por todo el pueblo, tanto en las casas como en el turno patronal. A pesar de la disminución de esta tradición por los efectos globalizantes, es importante que perdure, pues es un referente de la identidad local y de la herencia milenaria.

En la Figura 8 se aprecia el movimiento del arcángel en su eje principal en curva hacia la izquierda. Se observa el movimiento de cabeza y mirada hacia arriba a la izquierda, brazo derecho que levanta su espada, con significado de libertad y de fuerza, de la exterminación física, para defender las fuerzas luminosas o celestiales de las tinieblas y lo diabólico; el brazo contrario sostiene la balanza, símbolo del castigo y la culpa, a la justicia inminente. Es por eso que el arcángel Miguel posee uno de los rangos más altos, pues defiende de las fuerzas del demonio que, en otras representaciones, es aplastado con sus pies. Luego se dirige al movimiento 
de caderas, piernas y torso, hasta sus pies; todo posee ejes diagonales. En la nube representada, según Bachelard, simbólicamente se asocia a los mensajeros, en este caso a los ángeles y arcángeles como transmisores del anuncio de lo alto (Cirlot, 2008). Aparte del arco que forma el cuerpo, el ritmo se conjuga con el movimiento arqueado de las alas y recorrido visual a través de los puntos focales de ambas manos, rodilla derecha, los pies, la balanza contrapone el movimiento en sentido contrario y como punto principal que remata en la cabeza del arcángel. Esto provoca un fuerte cruce de movimientos, en sentido de una escultura abierta y no hierática.

Figura 8. Análisis compositivo estructural de la imagen de San Miguel Arcángel.

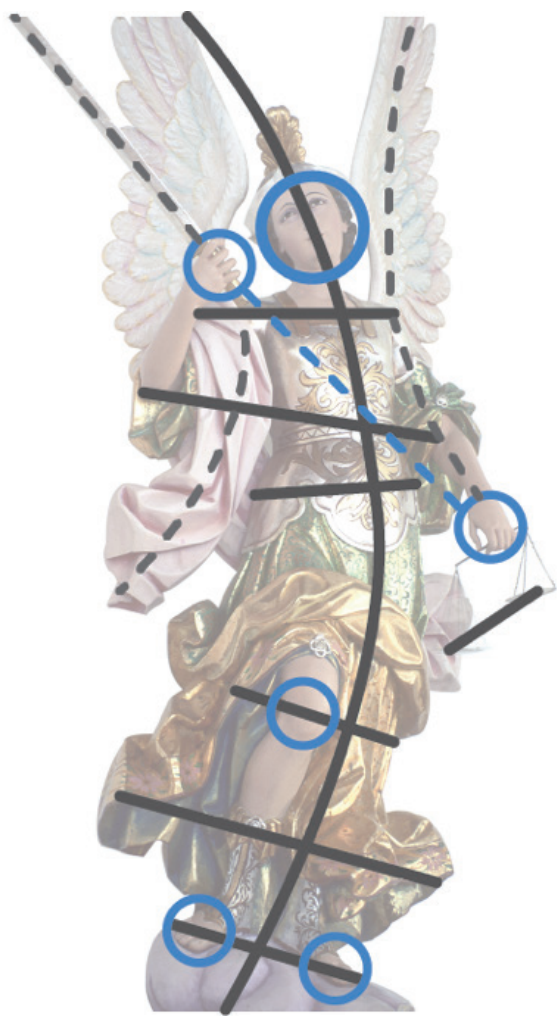

Fuente: Vargas, 2018.

El arcángel de este pueblo es el protector contra las fuerzas malignas, defensor y ente más cercano ante el creador, así como guerrero que lucha contra las fuerzas ocultas y acerca a la presencia celestial. Es el que expulsa al abismo, a lo bajo, oculto y oscuro, a lo negativo. Estar cercano a lo celeste es estar cerca de la luz, de la verdad, de la victoria, del triunfo, del jefe del ejército celestial y protector de la iglesia. Santos Chacón y Francisco Sánchez imprimen estos efectos al pueblo de Tibás o Villa Vieja, pero también el arcángel ejemplifica aquellos guerreros ancestrales y prehispánicos cercanos al sol, a Kukulkán, o serpiente emplumada entre los mayas, representación que también se tuvo en la zona de la Gran Nicoya. Para los nahuas es Quetzalcóatl, símbolo de la fertilidad y héroe cultural entre los toltecas y mayas que luego llega a México (también era el dios viento). Un rasgo particular es que Quetzalcóalt baja 
al inframundo o mundo de los muertos y fertiliza los huesos para crear una nueva humanidad, mientras que el arcángel Miguel, en su escena apocalíptica, expulsa a los abismos a los demonios rebeldes y con ello salva a la humanidad.

Existen otros elementos propios de ese barroco latinoamericano expresado en la finura de la talla en madera, en donde la pintura de su traje y la exuberancia de hojas alargadas, flores y pluma de su corona, así como se mencionó, lo poseen representaciones precolombinas de la fertilidad, de la amplia variedad faunística del trópico. En las imágenes siguientes (Figuras 9 y 10) se aprecia las hojas alargadas tomadas del chaleco o armadura del arcángel y luego un detalle de las flores de la parte inferior de su traje. Aunque es una talla de 1877, la manufactura conserva varios de los rasgos característicos de la escultura guatemalteca del siglo XVIII, especialmente, en los detalles de su armadura y vestimenta.

Figura 9. Detalle de representación de flor en la capa inferior del arcángel.

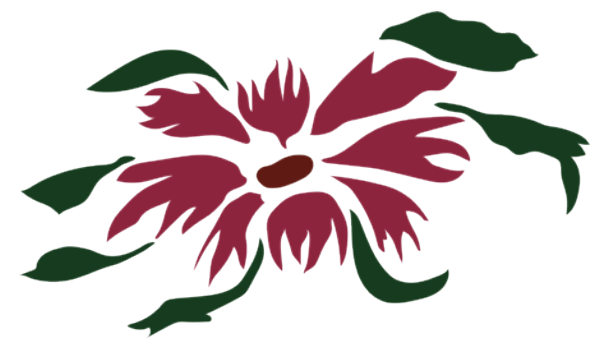

Fuente: Vargas, 2018.

Figura 10. Detalle de representación de hojas en la armadura del pecho del arcángel.

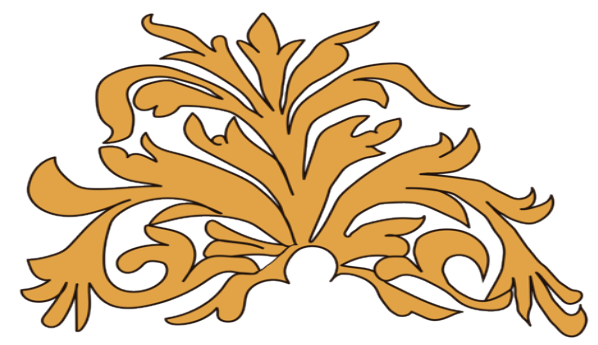

Fuente: Vargas, 2018.

Luego de la construcción del nuevo templo de San Miguel, la imagen del arcángel es llevada en procesión en el año de 1954 y hasta la fecha se mantiene en este sitio. En su lugar los vecinos colocaron la imagen de la Virgen del Monte Carmelo, una advocación que, de acuerdo con el historiador P. Manuel Benavides Barquero (Benavides, citado en Sojo, 2014), ya existía en la localidad de San Miguel Norte o Tures según registros de 1875, al contar con un oratorio en casa del señor Ramón Arce Benavides ${ }^{18}$. Posteriormente en 1896, se pide permiso para crear la cofradía de 
la Virgen de El Carmen en la Parroquia de Santo Domingo y se coloca una imagen en el altar en el sector norte de la Basílica (Archivo Arquidiocesano de San José).

La Virgen del Carmen o Nuestra Señora del Monte Carmelo se coloca después en el altar principal del templo que ocupó el Arcángel Miguel, también por iniciativa de los vecinos y por la existencia de esta devoción en el poblado de Tures. Mientras que San Miguel expulsa los ángeles rebeldes al infierno, la Virgen del Carmen está emparentada con el purgatorio. En el infierno, según Chevalier, su esencia

Es el propio pecado mortal, en el cual los condenados están muertos. Es la pérdida de la presencia de Dios, y como ningún otro bien puede ya ilusionar al alma del difunto, separada del cuerpo y de las realidades sensibles, ésta sufre la desgracia absoluta, la privación radical, tormento misterioso e insondable. Es el descalabro total, definitivo, irremediable, de una existencia humana. La conversión del condenado ya no es posible; endurecido en su pecado, está perpetuamente fijado en la pena (1986, p. 592).

Mientras que según el Catecismo de la iglesia Católica (2012) en el purgatorio están:

Los que mueren en la gracia y en la amistad de Dios, pero imperfectamente purificados, aunque están seguros de su eterna salvación, sufren después de su muerte una purificación, a fin de obtener la santidad necesaria para entrar en la alegría del cielo... La Iglesia llama purgatorio a esta purificación final de los elegidos que es completamente distinta del castigo de los condenados... Esta enseñanza se apoya también en la práctica de la oración por los difuntos, de la que ya habla la Escritura: "Por eso mandó [Judas Macabeo] hacer este sacrificio expiatorio en favor de los muertos, para que quedaran liberados del pecado" (2 M 12, 46). Desde los primeros tiempos, la Iglesia ha honrado la memoria de los difuntos y ha ofrecido sufragios en su favor, en particular el sacrificio eucarístico (cf. DS 856), para que, una vez purificados, puedan llegar a la visión beatífica de Dios. La Iglesia también recomienda las limosnas, las indulgencias y las obras de penitencia en favor de los difuntos.

En la tradición de la iglesia romana y en las bulas de varios de sus Papas afirman que la Virgen del Carmen rescata del fuego del infierno y del estado del purgatorio a los que lleven el escapulario y el hábito de tono café durante su vida, pues al llegar su muerte son purificados para luego pasar al reino celestial, como paso final y definitivo (Sgarbosa y Giovannini, 1987). Así que posterior al año 1954 los vecinos acogen en este templo antiguo esa nueva patrona, ya venerada desde antes en su pueblo y, año tras año, no solo celebran su festividad, sino que muchos visten su hábito o escapulario en procesión con esta imagen.

Ambas representaciones tienen una fuerte carga simbólica en donde se contraponen los opuestos: cielo-infierno, salvación-perdición, muerte-vida o muerteresurrección o sus afines, purgatorio igual purificación y salvación, escapulario carmelita (la purificación y salvación), espada de San Miguel (vencimiento ante el mal y salvación). Visualmente, así como existen representaciones del Arcángel aplastando la cabeza del demonio, existen representaciones de la Virgen del Carmen rescatando del fuego del purgatorio a sus ánimas.

no existía la Parroquia de Santo Domingo y que contaría con unos 73 años en 1975. Dato que debe precisarse en el futuro con nuevas fuentes. 
La representación artística mariana colocada en su altar principal corresponde a la imaginería del siglo XIX, tallada en Costa Rica. A los artistas imagineros se les conoce en el país también como santeros. Reymundo Méndez Montero (1997) agrega al respecto:

Los imagineros o tallistas de imágenes representan profesiones diversas más o menos especializadas: escultor, encarnador, dorador, estofador y pintor. Además de tallar imágenes, se dedicaban a decorar mobiliarios religiosos (altares, retablos, púlpitos, sillerías de coro, etc.) y a la ornamentación arquitectónica ...

En Europa y América colonial los imagineros formaron poderosas corporaciones o gremios dedicados a la edificación religiosa de sus fieles (p. 19).

La representación de imágenes sobre Jesucristo, las distintas denominaciones marianas, santos, entre otros, se tallaban en madera en bulto o relieve. La que nos ocupa es una escultura de vestir, imagen que posee esculpida su cabeza, ojos de vidrio, brazos articulados y el Niño Jesús de cuerpo completo que carga en un brazo. La imagen de la Virgen tiene una estructura del torso hacia abajo, pero sin pies, y además se le coloca cabello natural. A la imagen se le viste con su traje carmelita, así como al Niño, y un escapulario en su mano derecha. Luego sus partes visibles son estucadas y pintadas. En la Figura 11 se contempla la patrona actual del templo, luciendo su manto café, el escapulario y el Niño en su brazo izquierdo.

Figura 11. Fotografía de la imagen de Virgen del Carmen. Imaginería religiosa costarricense, cerca de inicios del siglo XX.

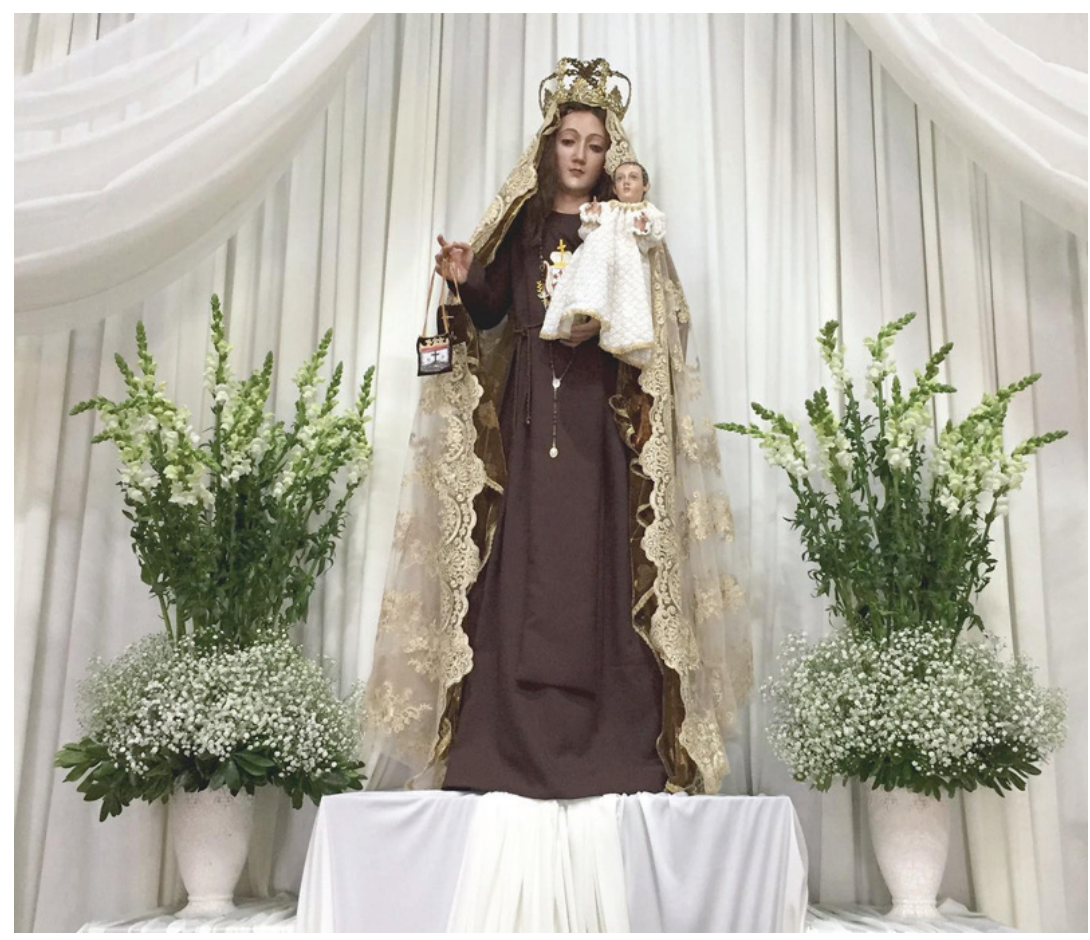

Fuente: Vargas, 2017. 
La erección de este templo toma en cuenta la oposición del subalterno frente al plano hegemónico y no lo comúnmente contrario. Es por eso que el texto fundacional del Templo de San Miguel posee un valor dóxico fundamental para entender que la concepción de este espacio sagrado, en esa locación costarricense, parte de una necesidad del pueblo unido para su levantamiento, construcción y estética, en donde no es la imposición de una orden religiosa, como sucede en otros sectores o países latinoamericanos, ni la de su cura párroco, el dominico Benito Sáenz y Reyes (18321919) (Lobo, s. f.) quien posteriormente gestiona la construcción de la Basílica de Santo Domingo de Heredia a partir de 1881 y que se prolonga por diez años (Bolaños, 1999). Por tanto, la construcción de este espacio sagrado nace desde la subalternidad y se impone en el desarrollo local de un pueblo costarricense.

Figura 12. Fotografía de vista parcial del templo patrimonial de El Carmen. San Miguel, Santo Domingo, Heredia.

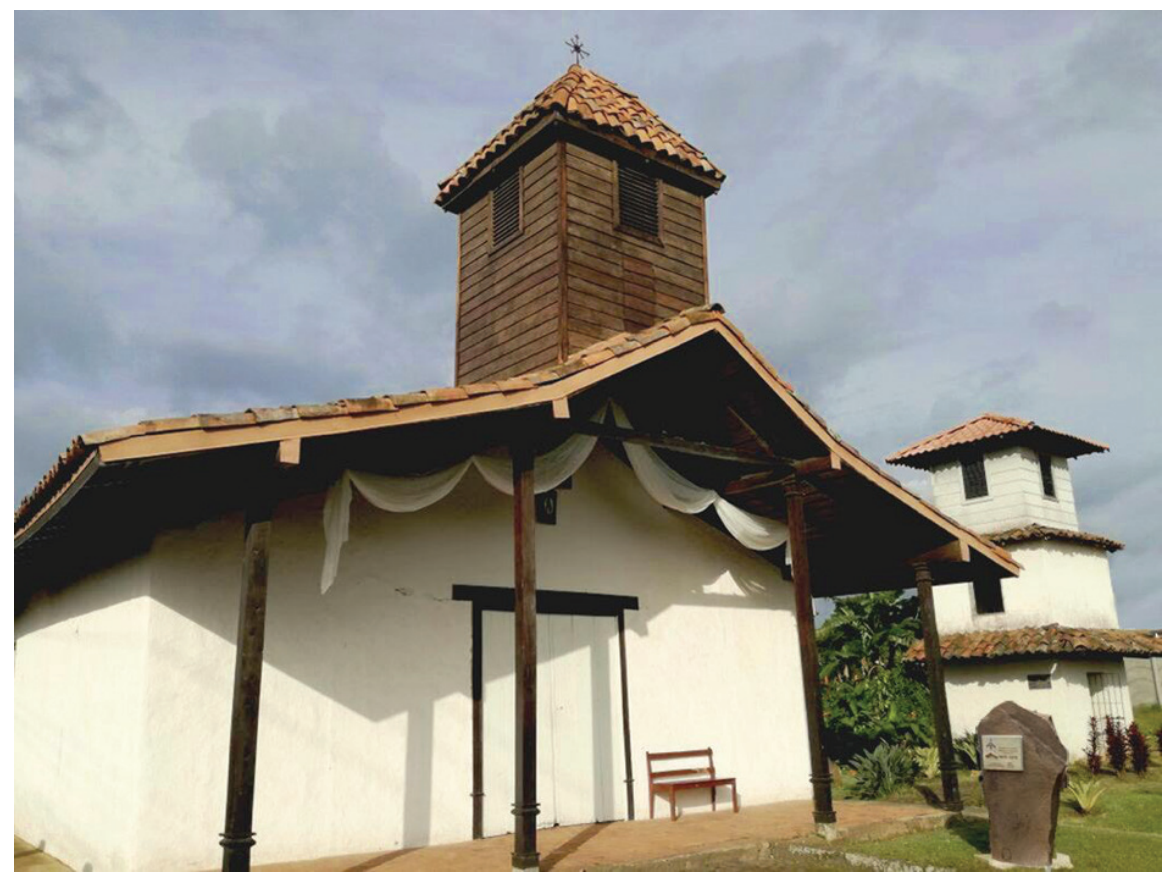

Fuente: Vargas, 2017.

\section{Conclusiones}

La casa de adobe forma parte del imaginario nacional, por lo cual se convierte en un referente dentro del paisaje y "símbolo patrio". Como lo menciona Eugenio Murillo (2000), esta aparece como tema en la pintura costarricense a finales del siglo XIX y se convierte en una imagen de marca y producto de la identidad nacional con la generación de la plástica nacionalista en la década de 1930. A pesar que se construye en su mayoría en el Valle Central y Guanacaste, se convirtió en ícono del imaginario costarricense.

En Costa Rica, el código sísmico "prohíbe el uso estructural de materiales y sistemas constructivos como adobe, tapial, bahareque relleno y mampostería sin refuerzo" 
(Aranda, González y Rotondaro, 2017, pp. 507-519). Esto a diferencia de otros países latinoamericanos e iberoamericanos, en donde se concibe la construcción, se analiza y estudia en universidades y carreras de arquitectura e ingeniería a través de la Red Iberoamericana PROTERRA ${ }^{19}$. La prohibición en Costa Rica se dio en el año de 1910, producto del terremoto de Cartago, y con esto no se permitió más sus construcciones. A pesar de catalogarlas como inestables, la restauración del Templo Patrimonial del Carmen se convierte en ícono de la restauración y conservación en Santo Domingo que posee más de 140 años a la fecha. En el país existen cinco iglesias de adobe y tres de bahareque ${ }^{20}$, además de otro número significativo de viviendas construidas con este material (Esquivel, 2016a, p. 182). Una buena construcción, restauración y conservación permite que este tipo de edificaciones vernáculas perviva a lo largo del tiempo. La arquitecta María Bernadette Esquivel comenta que gracias a la restauración del Templo El Carmen en San Miguel se despierta un interés nacional que ha desarrollado talleres por lo que se expone lo siguiente:

Es en este sentido en el que el Estado y la sociedad costarricense podrían volver su mirada a la arquitectura de tierra y contar con procesos de formación continua para lograr la transferencia de esa memoria a las futuras generaciones (Esquivel, 2016b, p. 321).

Esto demuestra que construcciones hechas de forma adecuada han pervivido en el tiempo a pesar de los eventos sísmicos que continúan presentes en el país. La construcción vernácula de este templo y otras viviendas en Santo Domingo con tamaños de adobes adecuados, estructuras de amarre de época, colocación de soportes y techos de madera y tejado, hacen que se mantengan a lo largo del tiempo. Como paisaje cultural, el templo herediano es un museo vivo que mantiene su uso y que contiene muchos más elementos históricos propios de la época de finales del siglo XIX e inicios del XX. Hale, citado por Gutiérrez (2007), define una característica base en este tipo de viviendas de barro:

Las casas de Costa Rica son las mejores de Centro América para resistir a las sacudidas. Son bajas y largas y están construidas con adobes o ladrillos sin cocer de dos pies de largo y de uno de ancho, fabricados con barro y que mezclan con paja para darle consistencia (Gutiérrez, 2007, p. 9).

Las medidas de la descripción de Hale en 1929 corresponden exactamente a las del tamaño de los adobes del templo en estudio. Esto demuestra su duración a lo largo del tiempo, así como su adecuada restauración de 2012.

A pesar de que muchas viviendas han sido demolidas en la zona de estudio, el Templo Patrimonial de El Carmen, su representación imaginera y simbólica, así como

19 La Red PROTERRA ha contribuido a los distintos procesos de reglamentación de la arquitectura y la construcción con tierra en Iberoamérica de varias maneras. Se destacan las publicaciones y las actividades de difusión y transferencia de conocimientos en talleres durante más de 10 años en distintos países; la difusión masiva por las redes académicas y científicas en general y a través de los contactos de sus miembros, investigadores y técnicos, realiza una promoción múltiple, intersectorial y estratégica en distintas universidades, ciudades y países.

20 El Centro de Investigación y Conservación del Patrimonio Cultural del Ministerio de Cultura y Juventud de Costa Rica contabiliza cinco iglesias construidas con materiales de tierra que aún permanecen: Antiguo Templo Católico Inmaculada Concepción, en Alajuela, Templo Católico NS Inmaculada Concepción, San Nicolás de Cartago, Templo Católico Nuestra Señora de El Carmen, San Miguel de de la Agonía, Liberia, Guanacaste. 
las celebraciones anuales de su patrona y demás actividades religiosas y culturales, demuestran la permanencia de este espacio en la memoria local y nacional. Este ícono continúa vivo en el pueblo migueleño y así como se erigió desde una subalternidad entre 1878 a 1879, sigue constante su interés por conservarlo y estudiarlo.

De igual manera se restauró el templo inapropiadamente durante el año de 1981, debido al desconocimiento del momento, pero se volvió a restaurar en el año 2012. Es importante que imágenes como la del arcángel se restauren de manera adecuada para que recupere su tono original; esto supondría un estudio cuidadoso al respecto. Así, también hace falta en nuestro país que más especialistas e instituciones apoyen estas labores de renovación y creación de nuevas políticas al respecto, capaces de amparar el valor patrimonial que posee Costa Rica.

\section{Referencias}

Archivo Arquidiocesano. (1979). San Miguel de Santo Domingo. N. 22-B.

Aranda, Yolanda, Ariel González, y Rodolfo Rotondaro. (2017). Avances y alcances de las normas de la construcción con tierra en Iberoamérica. Una aproximación. $17^{\circ}$ SIACOT. Seminario Iberoamericano de Arquitectura y Construcción con Tierra "Tierra - Identidades", La Paz: FAADU-UMSA, PROTERRA.

Benavides, Manuel. 2012. En Sojo, Óscar (2014). Inauguración de la ermita del Carmen, San Miguel de Santo Domingo, Heredia. [Documental].

Bolaños V., Rafael. (1999). Al Occidente del Abra. Historia monográfica de Santo Domingo de Heredia. (Colaboración de Floria Arrea Siermann y la Comisión de Cultura de la Municipalidad de Santo Domingo). Heredia: Editorial Centro de Estudios e Investigaciones Sociales.

Bolaños, Rafael. (2018). Breve reseña de San Miguel de Santo Domingo. En ADEPA. Antología de artículos. Puntos de Cultura. Santo Domingo Cultural: participación y desarrollo en el disfrute del patrimonio cultural domingueño. (pp. 33-34). Santo Domingo de Heredia: ADEPA.

Centro de Conservación delPatrimonio Cultural. Consultas Inmuebles declarados patrimonio. Recuperado de http://www.patrimonio.go.cr/map/01_sanjose

Chevalier, Jean. (1986). Diccionario de símbolos. Barcelona: Helder.

Esquivel, María Bernadette. (2016a). Prevención, conservación y restauración en Costa Rica. En Arquitectura de tierra en América Latina. (pp. 182-184). Lisboa: Argumentum y Proterra.

Esquivel, María Bernadette. (2016b). Capacitación y transferencia tecnológica en Costa Rica. En Arquitectura de tierra en América Latina. (319-321). Lisboa: Argumentum y Proterra. 
FamilySearch. La Iglesia de Jesucristo de los Santos de los últimos días. Recuperado de https://www.familysearch.org

González, Célimo. (1991). Antaño y hogaño del distrito de San Miguel de Santo Domingo de Heredia. Heredia: Departamento de Publicaciones Universidad Nacional.

González, Gonzalo. (2016). Lagartillal ayer, Pará hoy, mi San Luis de siempre. Heredia: manuscrito inédito.

Grube, Nikolai. (2000). Los mayas. Una civilización milenaria. Colonia: Könemann.

Gutiérrez, Manuel. (2007). La casa de adobes costarricense. San José: Editorial UCR.

Herrera, Ana Isabel. (2009). Monseñor Thiel en Costa Rica: visitas pastorales 1880-1901. Cartago: Editorial tecnológica de Costa Rica.

ICOMOS. Costa Rica. PROVINCIA DE HEREDIA. DECLARATORIAS PATRIMONIALES DE BIENES INMUEBLES. (Tutelados por la Ley 7555 del 20 de octubre de 1995). Recuperado de http://www.icomoscr.org/ content/index.php?option=com_content\&view=article\&id=65:patrimonioheredia\&catid=37:patrim-arquitect\&ltemid $=63$

Iglesia Católica. (2012). Catecismo de la Iglesia Católica. Ciudad del Vaticano: Libreria Editrice Vaticana.

Iturriga, José. (2015). Historia ilustrada de México. Gastronomía. Ciudad de México: Debate y Conaculta.

Méndez, Raymundo. (1997). Lico Rodríguez. Escultor de imaginería religiosa. San José: Editorial UNED.

Mobil, José (1995). Historia del arte guatemalteco. Ciudad de Guatemala: Serviprensa Centroamericana.

Molinier, María. (1970). Diccionario de uso del español. Madrid: Gredos.

Monge, Grettel. (2012). Informe final. Evaluación de los recurso arqueológicos del terreno destinado al Nuevo Centro de Control de Energía, San Miguel de Santo Domingo de Heredia. Unidad Estratégica de Negocios, Proyectos y Servicios Asociados. Centro de Servicio Gestión Ambiental. ICE.

Murillo, Eugenio. (2000). ¡UUUUUPEEE! Llamando ante la casa de adobes. Análisis sociocrítico del "símbolo patrio" de la casa de adobes, en su dimensión pictórica. Káñina, Revista de Artes y Letras, XXIV(2), 111-124.

Noriega, F, Félix. (1904). Diccionario geográfico de Costa Rica. San José: Imprenta de Avelino Alsina. 
Oconitrillo Lobo, Óscar. (s.f.). Sacerdotes diocesanos y religiosos en Costa Rica: 1800-2015. Boletín CEHILA. Recuperado de https://boletincehila. wordpress.com/2017/03/09/los-religiosos-en-costa-rica/

Ortiz, María Salvadora. (1988). En torno al barroco Latinoamericano: dos aporte: Severo Sarduy y Alejo Carpentier. Káñina, Revista de Artes y Letras, XII(1), 57-63.

Rigol Sabio, Isabel. (2004). CCBP. Programa de desarrollo de capacidades para el Caribe. Para el Patrimonio Mundial. Gestión de paisaje culturales. (Módulo 4). La Habana: UNESCO.

Rodas, Harold. (1992). Pintura y escultura hispánica en Guatemala. Ciudad de Guatemala: Universidad de San Carlos.

Sgarbossa, Mario y Giovannini, Luigi. (1987). Un santo para cada día. Bogotá: Ediciones Paulinas.

Solórzano, Gerardo. (2014). Agricultura Güetar. Cartago: Editorial Tecnológica de Costa Rica.

Wikipedia. La enciclopedia libre. (s.f.). Cantón de Santo Domingo (Costa Rica). Recuperado de https://es.wikipedia.org/wiki/Cant\%C3\%B3n_de_ Santo_Domingo_(Costa_Rica).

\section{Entrevistas:}

Esquivel, Bernadette y Vargas, Henry. Entrevista realizada a Nidia Villalobos Palma y a María Aurelia Azofeifa, 5 de noviembre de 2016.

Vargas, Henry. Entrevista realizada a Emilce Salas Chacón, 27 de agosto de 2017.

\section{Anexo}

\section{Archivo Histórico Arquidiocesano, San José, Costa Rica \\ (Transcripción del manuscrito)}

1879

$\mathbf{N}^{\circ}-22-\mathrm{B}$

San Miguel de Santo Domingo.

Varios vecinos piden el permiso para la construcción de una Iglesia, bajo la advocación de San Miguel

Papel de 50 centavos

llustrísimo y Reverendísimo Señor Obispo

Los que suscribimos de distintas edades, estados í profesiones í vecinos del Barrio de San Miguel, Cantón de Santo Domingo ante S. Ilustrísimo í Reverendísimo con el más profundo respeto venimos a exponer, llevados de los más puros y sinceros sentimientos, 
que siempre nos á animado hacia la religión Santa de Jesucristo, la cual profesamos con todas las venas nuestro corazón, desde niños habitando, como habitamos un pueblo que se halla a la distancia de más de una í media leguas de la parroquia del Cantón referido, existiendo además en la travesía del camino que conduce de nuestro pueblo a la cabecera del Cantón un río caudaloso que, principalmente en la estación de invierno, impide completamente el paso por carecer de puente, nos propusimos hacer venir de Guatemala, una imagen de nuestro Patrono San Miguel, procurando fuera de la mejor escultura, de vara í media de altura í del grueso correspondiente con la misma altura, cuya imagen tenemos en efecto desde abril del año setenta í siete.

Con este motivo pensamos enseguida en construir una casa con la forma í construcción de una ermita en donde pudiéramos colocar dicha imagen í tributarle en ella culto í adoración al Ser Supremo í la construimos en efecto en la estación de verano del año setenta í ocho, de veinticuatro varas de largo por once de ancho, con tres navecitas, montada en pared de adobe, de madera labrada, cubierta con teja del país, ubicada en un solar (que dos vecinos donaron formalmente al Santo Patrono) de suficiente extensión, aún para edificar más si fuere necesario, la cual está concluida perfectamente. Luego construimos en dicha casa un altar medianamente decente í adornando colocamos en él la referida imagen, dejando bastante espacio en el mismo altar para colocar el hara Santa, en que pudiera celebrarse el Santo Sacrificio de la misa si obtuviésemos el correspondiente permiso del ilustrísimo í Reverendísimo, que con el más profundo respeto hoi expresamos.

Con el objeto últimamente indicado compramos en efecto la piedra que nos ha se servir de hara í todos los ornamentos necesarios para la celebración del Santo Sacrificio í un par de campanas pequeñas.

En este estado í acercándose ya el día de Nuestro Santo Patrono deseando celebrar esa fiesta en la casa, de que hemos hecho mención, tributando culto a nuestra imagen í adoración al Ser Supremo, venimos implorando la gracia de que Su llustrísimo y Reverendísimo nos conceda el permiso correspondiente para celebrar ese día el Santo Sacrifico de la misa í continuar pudiéndole celebrar todos los domingos í días de fiesta para poder de este modo cumplir con religiosidad í exactitud nuestros principales deberes religiosos en los días de precepto eclesiástico, evitando así faltar a ellos como muchas veces nos sucede a consecuencia de los motivos que dejamos indicados, decretando por consiguiente prévia bendición de dicha casa, siquiera sea con el carácter de Oratorio-público í demás ceremonias que el derecho canónico prescribe para casos semejantes.

En el pueblo de que venimos hablando hay ya una población de más de cuatrocientos habitantes, en cien casa habitadas permanentemente, fuera de otras que residen en el por temporadas o estaciones, o sea unas cien familias distintas, í lo que podemos asegurar es que todas ellas están animadas de los más íntimos sentimientos religiosos í del mayor entusiasmo, por obtener en nuestro pueblo un lugar de oración y culto donde podamos reunirnos para elevar al Ser Supremo nuestros corazones í pedirle los auxilios de la gracia divina, para vivir siempre cumpliendo nuestros deberes morales religiosos í civiles í obtener a nuestra muerte la eterna bienaventuranza.

Estos son nuestros sentimientos, í confiando en que S. Ilustrísimo y Reverendísimo los secundará atendiendo a su indulgencia y a su decidido empeño en la propagación de la doctrina evangélica en todos los ámbitos de la Diócesis que tan dignamente presides, 
a cuyo objeto contribuye sobre manera la construcción de templos, S. llustrísima í Reverendísimo acudimos hoi pidiendo la gracia de que hemos hecho referencia í la cual imploramos con el más profundo respeto y con todo el anhelo de nuestro corazón.

Santo Domingo, julio 21 de 1879

Firman:

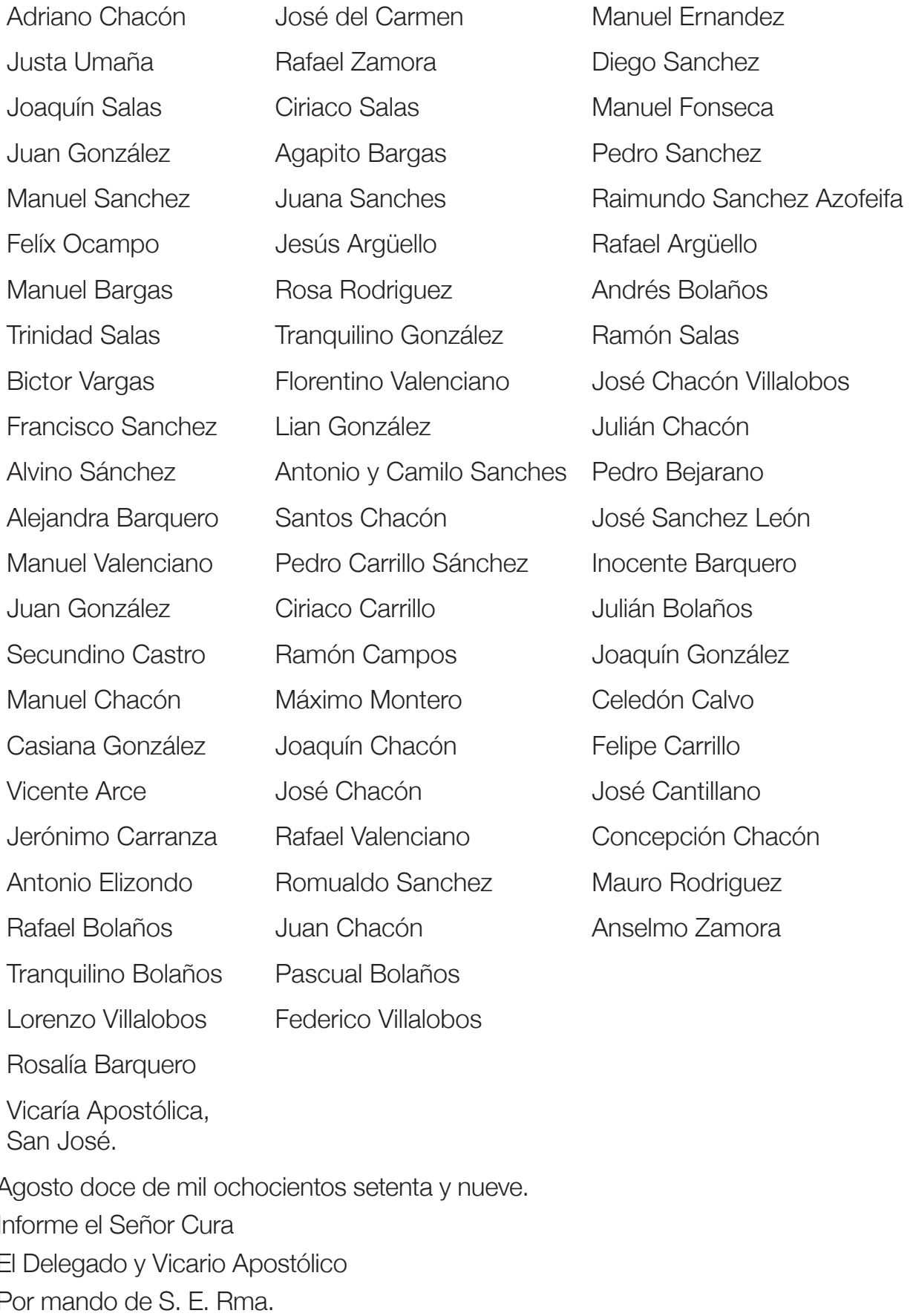


El que suscribe impuestos de este auto y del escrito anterior, pasa a informar que es cierto lo dicho en el y que le parece justo acceder a la solicitud de aquel vecindario que se compone en su mayor parte de gente mui piadosa para estimularlo y trabajar, por ser aquella población pequeña hoi, llamada a ser con el tiempo grande, tal vez una ciudad, siempre que no se grave al cura pro tempore de esta parroquia, porque sería imposible casi atender aquella Iglesia, por las razones dichas en el escrito que encabeza este expediente que son, la distancia, que según algunos es de dos leguas, el río peligroso y los malos caminos. Los dicho cree el Cura que firma sea bastante para cumplir con lo que le manda.

Santo Domingo, agosto 20 de 1879

Benito Sáenz (Cura Párroco) 